\title{
Urinary ratio of sodium and potassium in Irish Adults
}

Cardiovascular Disease (CVD) is one of the leading causes of morbidity and mortality in the world accounting for approximately one third of global deaths. A diet low in sodium $(\mathrm{Na})$ and high in potassium $(\mathrm{K})$ is widely recommended as a strategy to lower blood pressure and to reduce the risk of CVD. The independent roles that both sodium and potassium play in blood pressure have been long established, however in recent times increasing evidence has suggested that an individual's Na: $\mathrm{K}$ ratio is a more important predictor of hypertension than either sodium or potassium intake alone. The Food Safety Authority of Ireland (FSAI) recommends that Irish adults should consume no more than $6 \mathrm{~g}$ of salt $/ 2.4 \mathrm{~g}$ of sodium per day ${ }^{(1)}$. The US Institute of Medicine (IOM) has set an AI (adequate intake) for potassium at $4.7 \mathrm{~g}$ for adults of all ages ${ }^{(2)}$. 24-hour urinary excretion of sodium and potassium closely reflects daily intakes. The World Health Organisation (WHO) recommends a urinary molar Na:K of $\leq 1.0^{(3)}$ based on meeting the WHO guidelines for intakes of $\mathrm{Na}$ of $<2000 \mathrm{mg} / \mathrm{d}$ and $\mathrm{K}$ of $>3510 \mathrm{mg} / \mathrm{d}$. The objective of this study was to estimate the mean $24 \mathrm{hr}$ urinary $\mathrm{Na}, \mathrm{K}$ and Na:K of Irish adults. Analysis was based on the National Adult Nutrition Survey (NANS) (2008-2010) (www.iuna.net), in which a nationally representative sample of Irish adults $(n$ 1500) completed a 4-d semi-weighed food diary with $75 \%$ of participants providing spot urine samples. Urinary $\mathrm{Na}$ and $\mathrm{K}$ was determined using a Randox Rx Daytona with an ion selective electrode. Mean $24 \mathrm{hr}$ excretions of sodium and potassium were corrected for gender specific $24 \mathrm{hr}$ urine volume estimations based on a study by Perry et al ${ }^{(4)}$. SPSS Version 21 for Windows ${ }^{\mathrm{TM}}$ (SPSS, Inc.) was used for all analyses.

Mean $24 \mathrm{hr}$ urinary excretion of $\mathrm{Na}$ and $\mathrm{K}$ indicate that mean salt intake exceeded the FSAI population target of less than $6 \mathrm{~g} / \mathrm{d}$ while mean $\mathrm{K}$ intakes were lower than the IOM AI $(4.7 \mathrm{~g} / \mathrm{d})$ across all age and sex groups. The average molar ratio of Na:K was 2.50 for men and 2.75 for women. At an individual level, compliance with the WHO recommendation for a molar Na:K of $\leq 1.0$ was very low (2.4-12.2\%). Strategies to reduce $\mathrm{Na}$ and increase $\mathrm{K}$ intakes will be needed to lower the Na:K ratio which may help to reduce the burden of cardiovascular disease in the Irish population.

Table 1. $24 \mathrm{hr}$ urinary sodium, salt and potassium, urinary molar ratio of $\mathrm{Na}: \mathrm{K}$ in Irish adults by age-group and gender

\begin{tabular}{|c|c|c|c|c|c|c|c|}
\hline & & Urinary sodium $(\mathrm{g})$ & Urinary salt equivalents (g) & Urinary potassium(g) & $\begin{array}{r}\text { Urina } \\
\text { rati } \\
\end{array}$ & $\begin{array}{l}\mathrm{K} \text { olar } \\
\end{array}$ & \\
\hline & $N$ & Mean & Mean & Mean & Mean & $\mathrm{SD}$ & $\%<1.0$ \\
\hline Men & 541 & 4.63 & 11.6 & 3.89 & 2.50 & 1.49 & 11.1 \\
\hline $18-35$ years & 217 & 4.68 & 11.7 & 3.78 & 2.59 & 1.57 & 11.5 \\
\hline $36-50$ years & 147 & 4.69 & 11.7 & 4.31 & 2.31 & 1.36 & 12.2 \\
\hline 51-64 years & 109 & 4.50 & 11.3 & 3.89 & 2.42 & 1.39 & 11.9 \\
\hline $65+$ years & 68 & 4.55 & 11.4 & 3.39 & 2.77 & 1.59 & 5.9 \\
\hline Women & 564 & 3.53 & 8.8 & 2.69 & 2.75 & 1.67 & 6.2 \\
\hline $18-35$ years & 197 & 3.93 & 9.8 & 2.89 & 2.95 & 1.92 & 6.1 \\
\hline $36-50$ years & 175 & 3.53 & 8.8 & 2.83 & 2.61 & 1.58 & 8.6 \\
\hline $51-64$ years & 110 & 3.28 & 8.2 & 2.51 & 2.68 & 1.55 & 5.5 \\
\hline $65+$ years & 82 & 2.90 & 7.2 & 2.14 & 2.65 & 1.28 & 2.4 \\
\hline
\end{tabular}

1. FSAI (2011) Dublin, Ireland: Food Safety Authority of Ireland

2. IOM (2005), Washington, DC: The National Academies Press

3. WHO (2012) Geneva, Switzerland: World Health Organisation

4. Perry IJ et al., (2010) Cork, Ireland: Safefood 